\title{
The Simplon-Orient Express. Multiple Identities in the Everchanging Central-European Landscape
}

\author{
Anton GosaR, Portorož/Portorose*
}

with 14 figures and 4 tables in the text

Figure 1: The train of author's life: the Borsig steam engine JDŽ 06 hauling the Simplon-Orient Express

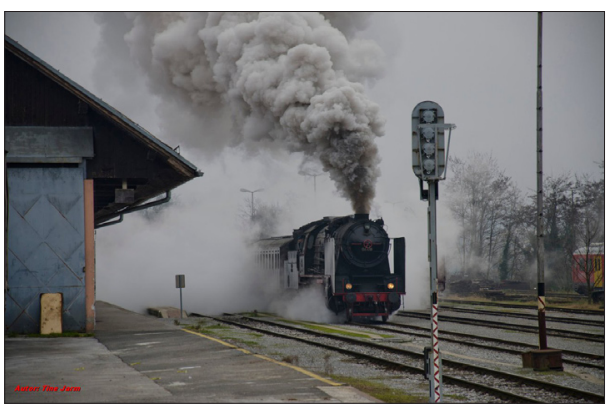

Our life is a train we have chosen to jump on, discover new horizons, intermingle with other passengers, and get off at a place we choose.

We are passengers on our chosen train of life. Conductors direct us to our anticipated seat. The departure of the train is set, the train route is marked, but the stations where we get off for a while to consume fresh air of experience and knowledge, are free to our choice. Before boarding our train again, we look at station displays to ensure we are at the platform of departure on time and do not miss the train traveling the route to which we are committed. The train comforts us. There are other trains of life we meet there. Some are closer some are more distant to our understanding of the train speed and stations of call. We might switch compartments if we feel uncomfortable, if our co-passengers annoy us, or even if we feel that occupants of the neighbouring compartments are more pleasing.

* Prof. Dr. Anton Gosar, University of Primorska, Faculty of Tourism Studies - Turistica, Obala 11a, SI-6320 Portorož/Portorose, Slovenia; email: Anton.Gosar@fts.upr.si 
For most of my life-time, my train of life was the Simplon-Orient Express - the train connecting cultures of East and West. The Simplon-Orient Express started to run in 1906 as the Simplon base-tunnel was opened. Therewith the Simplon-Orient Express replaced the previous Orient Express, which in 1883 started to run different routes from Central Europe to Istanbul [İstanbul].

\section{Figure 2: East meets West: the Simplon-Orient Express route Istanbul-London}

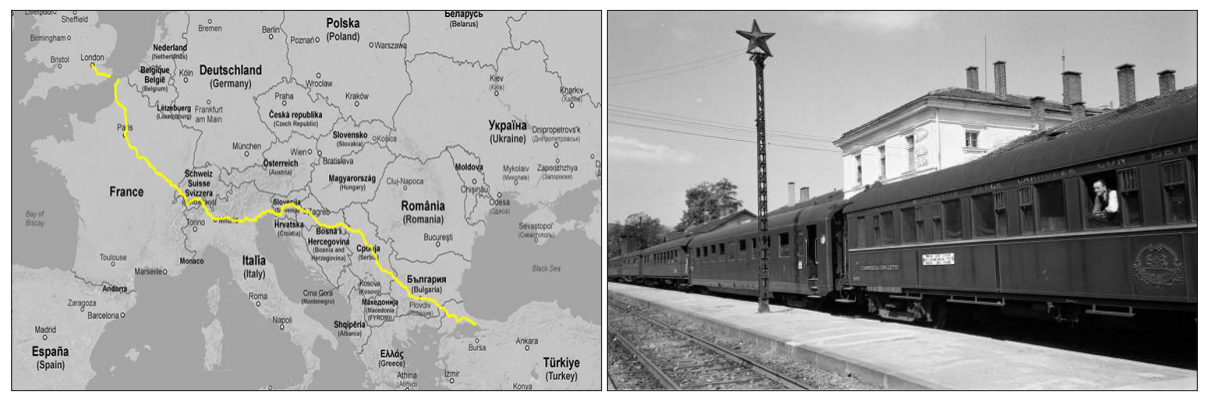

By the mid-thirties of the previous century the train, combined with the Taurus Express, enabled rides from/to Teheran [Tehran] and Baghdad [Bagdad], Damascus [Dimashk], Cairo [Al Kahira] and Tripoli [Tarabulus] (the train composition from Africa met Asian Pullman cars in Aleppo [Haleb], Syria), via Ankara and Istanbul to Milan [Milano], Paris and London. "Murder on the Orient Express", published in 1934 by Agatha Christie, is one of the best-known stories related to this train. On tracks west of Belgrade [Beograd] my train of life was pulled by the majestic JDŽ 06 steam engines. These engines were ordered in 1929 by the Yugoslav State Railways [Jugoslovenske državne železnice] and built at the Borsig factory in Berlin in the quantity of 30 within one year. Still, on his last trip, in 1977, the Simplon-Orient Express was drawn by this impressive JŽ 06 steam engine.

I was born in 1945. Travelling through life, I took every opportunity to catch fresh air of knowledge and experience on any station of the Simplon-Orient Express train: Istanbul, Skopje, Belgrade, as well Ljubljana, Munich [München], Paris and London have soon became part of me. Even more, in my first two encounters with America, in 1957 and 1962 (Ljubljana - Le Havre/Cherbourg - Ljubljana), the first and last leg of the trip was made by the Simplon-Orient Express with the Borsig engine JDŽ 06 in front.

As in the case of the Simplon-Orient Express steam locomotive, the YugoslavGerman heritage is part of my own train of life. I was born in an ethnically mixed German-Slovene family. My father was 'ethnically' a convinced Yugoslav, despite the fact that he was born in Slovenia and his family had Slovenian roots. As in October 1944 Soviet and Tito-partisan troops defeated the German Wehrmacht in Banat and liberated 
Belgrade, my pregnant autochthonous Vojvodina-German mother was placed into a concentration camp. After numerous appeals she was released one month ahead of my birth. My birthplace, the former Nagybecskerek, which turned to become Petrograd, was in 1945 re-named into Zrenjanin, hailing therewith a partisan commander.

Figure 3: Yugoslavia's East meets West: the Simplon-Orient Express route Istanbul-London

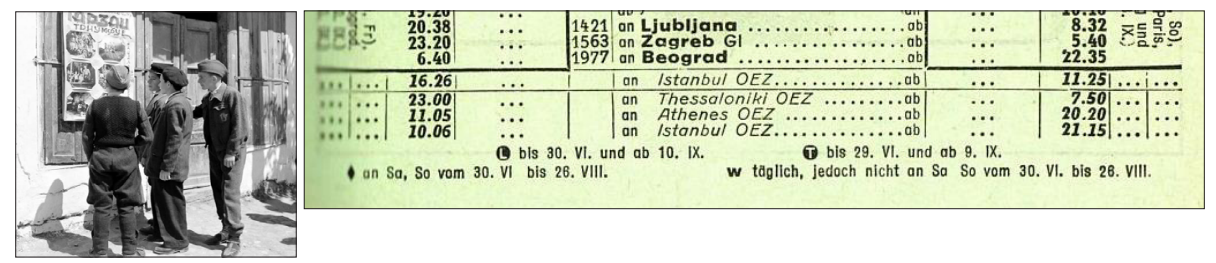

Besides Serbian, in the ethnically mixed Hungarian, Romanian, German and Serbian town, no other language was allowed to be used neither in public nor in private life. The term mother tongue had no meaning to me since my mother knew Serbian (and Hungarian) just basically, and German she had to hide. In the Kindergarten, I was taught in Serbian. The Yugoslav Communist government soon nationalized German property and therewith our house in the suburbs. As I was seven, my family decided to move to my father's family home-town. The whole property was placed into one railway carriage and then, in Belgrade, buckled up to the Simplon-Orient Express heading West. On the track next to the Simplon-Orient Express a seemingly freight train arrived; the train carriages had been occupied with emigrants originating from the karstic Lika with the intention to settle down in Vojvodina's villages left by Germans. To our Simplon-Orient Express co-passengers in the first class compartment (my father was employed by the JDŽ and had some privileges), ahead of the cargo carriage with our belongings, I proudly announced that I am a Serb from Banat ("Lala sa Banata") and that we are going to spend holidays in Slovenia. But co-passengers acted strange by commenting ... "how can this be, your parents are calling you Toni, and we don't know any Serb to have such a name and be dressed as you." By entering into the primary school in Slovenia, I was a convinced Serb, with no knowledge of Slovenian, and not of the so-called 'mother tongue'.

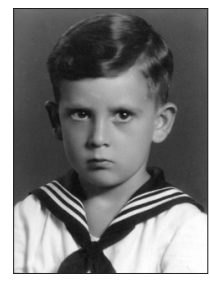

Figure 4: The author as "ethnic Serb" in a Slovenian-German household in Zrenjanin, Vojvodina (Yugoslavia) 
This conference is devoted to discuss the European Union's quick enlargement process of the past and to reconsider its consequences. The meeting's time-frame coincides also with the remembrance of the start of World War I - as huge empires disintegrated and as chauvinism became wings. The following century was marked by the hunt for territory and the quest for ideological, cultural and ethnic dominance. Nazism, Fascism, Communism, forced migrations and ethnic genocide have made roots in the European scene since then.

The fall of the Iron Curtain, about 25 years ago, and the EU's enlargement towards East, ten years ago, have finally turned the clock of time into direction of co-operation among nations of East and West. Or did they? The Vilnius Summit in November 2013 envisioned in a long-time projection the inclusion of Ukraine. Since this time relations on the European continent worsened! Crimea [Krim] was annexed to Russia's Federation based on ethnic circumstances, Eastern Ukraine rebels against the central government, seeking inclusion into Russia due to its dominant Russian ethnic population. Stepping forward with one's own ethnic beliefs seems to have become popular. Scottish and Catalan referendums prove that even the West is not immune from it.

Figure 5: Europe's geographic reality and future 2014

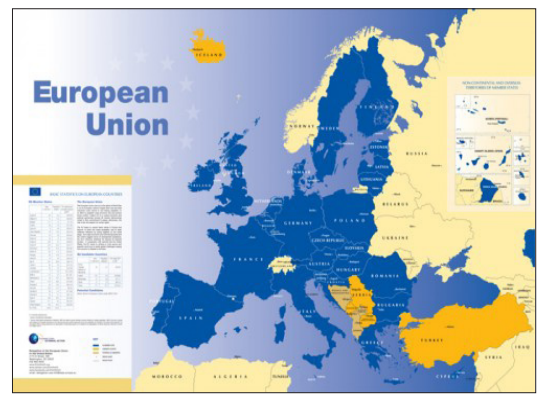

EU's geographic reality

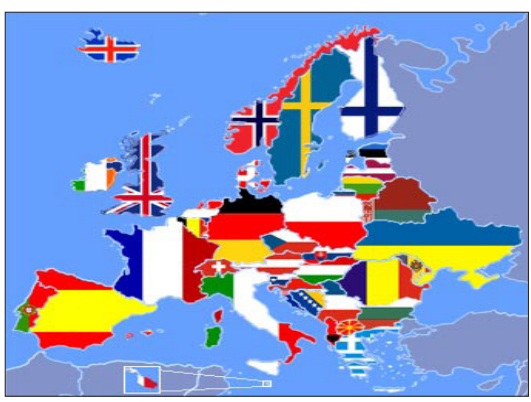

EU's geographic future?

Source: The European Union Bill and the Limits to Parliamentary Sovereignty - the Great Unravelling (an occasional blog by Charles REED, 2011)

In the last two decades, today's celebrity Peter JORDAN foresaw developments in numerous of his works, in particular in works related to the Ukraine and in his (and his colleagues') works on the ethnic consciousness in East-Central and Southeast Europe, published in the Atlas of Eastern and Southeastern Europe in 2006. With the title "ethnic consciousness" (German: Ethnisches Bewusstsein; Slovenian: Etnično prepričanje) he initially stated that the ethnic frame is a dynamic process and that a person and/or a group of people can switch identity during his/her lifetime and/or intensify that identity.

The strengthening of ethnic loyalty (ethnic self-esteem) as well as the change of loyalty from one to another ethnicity (ethnic identity) results out of subjective, political, 
economic and/or ideological causes. In Southeastern Europe, in the former Yugoslavia, we have had all four inputs in place: the switch from Communism to democracy, the split of rich from the poor, and the strengthening of identity based on territory and culture/religion. The Yugoslav ethnic identity, which in 1981 accumulated 1.4 million members or $7 \%$ of citizens, had no chance to survive. The general 're-ethnisation' has resulted in a major ethnic awakening, in the creation of several new, sovereign nation states, in interethnic wars, and, according to the UN high commissioner, close to four million displaced people.

Figure 6: Ethnic consciousness in Central and Southeast Europe around 2000
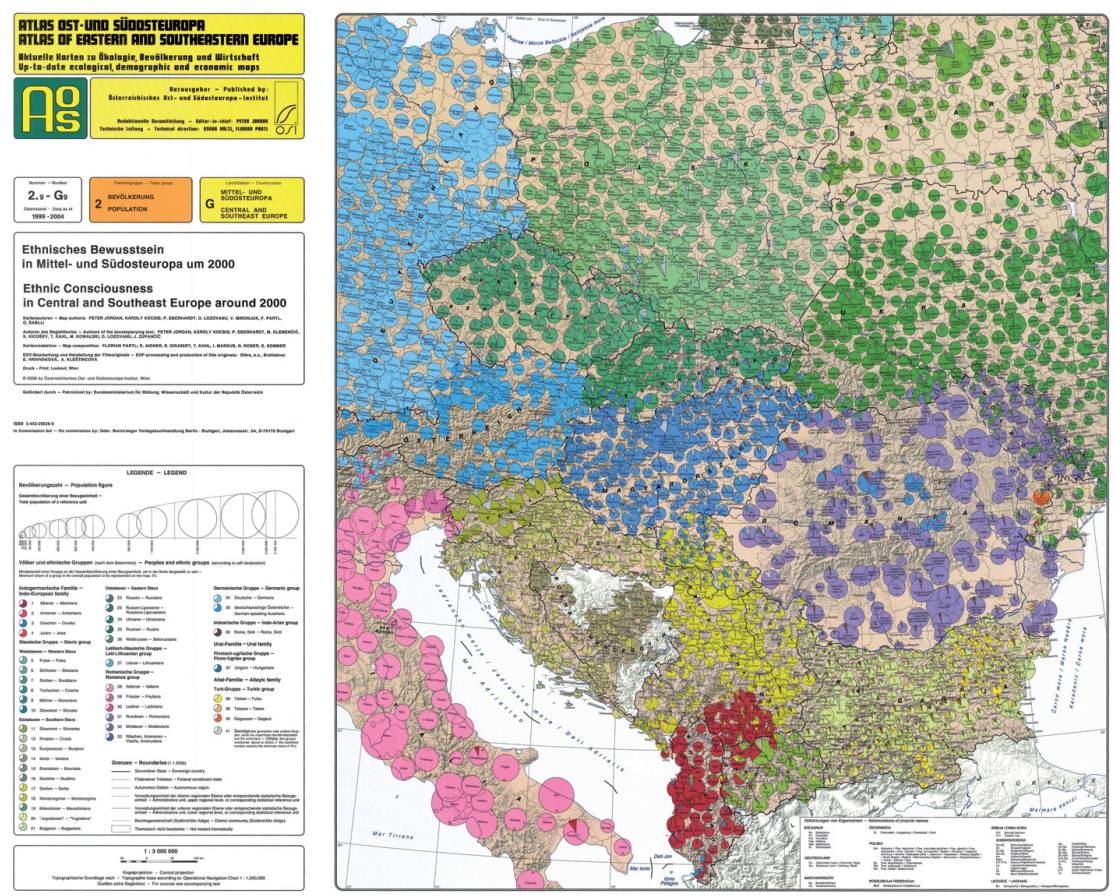

Source: JORDAN \& Kocsis et al. 2006

Regarding territorial division on ethnic lines, Bosnia and Herzegovina has become a major example. According to the Dayton Peace Agreement territorially dominant ethnicity is in the same state formally, by the so-called IEBL (inter-ethnic border line), separated from each other. Serbs' dominant spaces are separated from the Croatian and Bosniak, - well shown on Peter JoRDAN's map. From another perspective, this federation of two entities (Republika Srpska, Federacija BiH) is a perfect example of the case of the strengthening of the 'ethnic consciousness' among the Bosniak, earlier ethnic Muslim population. 
Figure 7: Exodus and territorial/political strengthening of ethnic identities in post-conflict Bosnia and Herzegovina
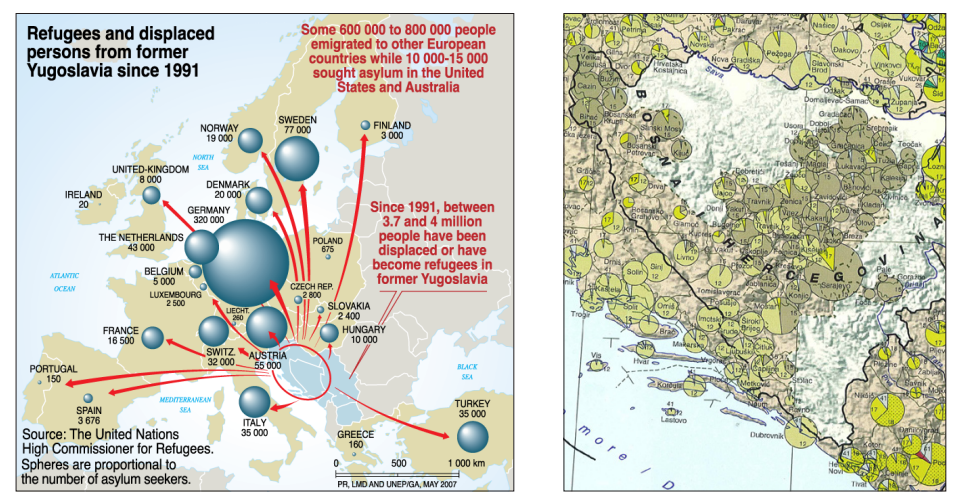

Sources: The United Nations High Commissioner for Refugees (left), Jordan \& Kocsis et al. 2006 (right)

On the other hand, the weakening of the ethnic consciousness of the Croats and stagnation of the citizens of Serb ethnic roots are a constant in Bosnia and Herzegovina on which the recent "Balkan wars" have had no major input. As shown on maps, the result of the confrontation and of the later peace settlement is definitely the clearer division between ethnic communities on the territory of the state. As stated by Hasić (2004), have the refugees, residing in Sweden, Germany, the U.S.A. and elsewhere, lost their original identity and live romanticizing former Yugoslavia. Limbo diasporas live with links to imaginative memory and associate with organisations of common interest in the host country.

Table 1: Federation of Bosnia and Herzegovina: Population by ethnic structure according to censuses

\begin{tabular}{|l|r|r|r|r|}
\hline & $1953(\%)$ & $1971(\%)$ & $1991(\%)$ & $2013(\%)$ \\
\hline Yugoslav & 31,3 & 8.4 & 5.5 & 4.3 \\
Bosniak & - & - & - & 48,4 \\
Muslim & 30,7 & 39.6 & 43.5 & - \\
Serbian & 44.4 & 38.2 & 32,2 & 32.7 \\
Croat & 22,9 & 20,6 & 17,4 & 14.6 \\
\hline POPULATION & $\mathbf{2 . 8 4 7 . 4 5 9}$ & $\mathbf{3 , 7 4 6 . 1 1 1}$ & $\mathbf{4 , 3 7 7 . 0 3 3}$ & $\mathbf{3 , 7 9 1 . 0 0 0}$ \\
\hline
\end{tabular}

Source: Savezni Zavod Za Statistiku SFRJ - Census Results of Yugoslavia 1953, 1971, 1991; Dnevni Amaz (Sarajevo, March 13, 2014; p.1) 
Figure 8: Bosnia and Herzegovina: Ethnic structure 2013

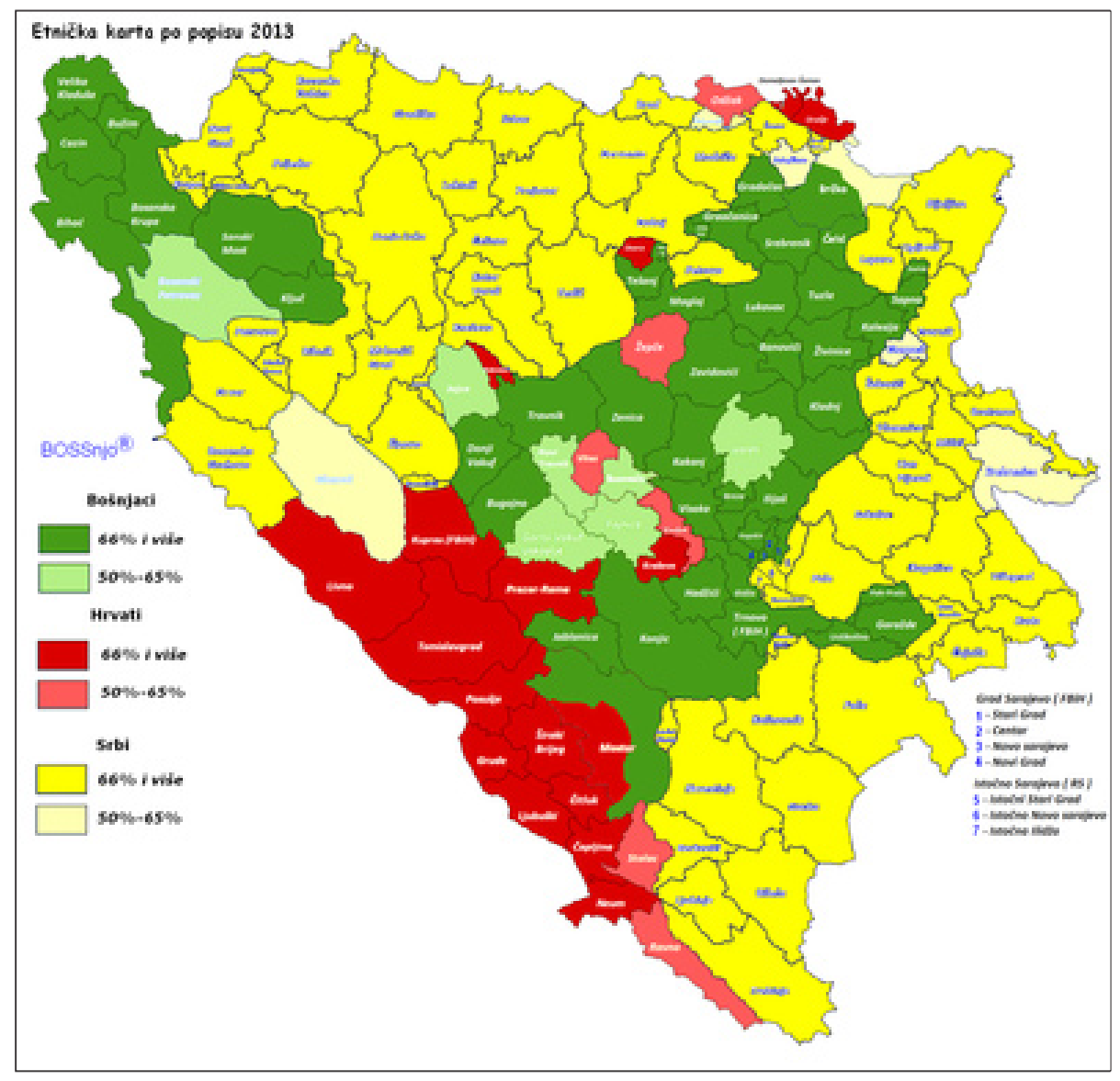

Source: Dnevni Avaz, March 13, 2014, p. 1

The demographic and ethnic awakening is nowhere else stronger at present than in the case of the Albanian nation. If we disregard the Albanian nation state and Kosova (Kosovo i Metohija) as dominant Albanian ethnic territory, Macedonia (Former Yugoslav Republic of Macedonia) proves the trend. As in 1953 just 12\% of the residents of the Macedonian Socialist Republic dared to declare themselves Albanian, the census of 2003 doubled that number. Macedonians remained always at a two-third level regarding origin. Turks, Serbs and Muslims almost disappeared. 
Table 2: FYR Macedonia: Population by ethnic structure according to censuses

\begin{tabular}{|l|r|r|r|r|}
\hline & $\mathbf{1 9 5 3}(\mathbf{\%})$ & $\mathbf{1 9 7 1}(\mathbf{\%})$ & $\mathbf{1 9 9 1}(\mathbf{\%})$ & $\mathbf{2 0 0 3}(\mathbf{\%})$ \\
\hline Macedonian & 66,0 & 69,3 & 65,3 & 64,2 \\
\hline Albanian & $\mathbf{1 2 , 5}$ & $\mathbf{1 9 , 8}$ & $\mathbf{2 2 , 7}$ & $\mathbf{2 5 , 2}$ \\
\hline Turks & 15,6 & 6,6 & 3,8 & 3,9 \\
\hline Roma & 1,6 & 1,5 & 2,6 & 2,7 \\
\hline Serbian & 2,7 & 2,8 & 2,1 & 1,8 \\
\hline Muslim/Bosniak & 0,1 & 2,1 & 1,5 & 0,9 \\
\hline Yugoslav & 0,1 & 0,2 & 1,5 & - \\
\hline POPULATION & $\mathbf{1 , 3 0 4 . 5 1 4}$ & $\mathbf{1 , 6 4 8 . 3 0 8}$ & $\mathbf{2 , 0 3 3 . 9 3 2}$ & $\mathbf{2 , 0 2 2 . 5 4 7}$ \\
\hline
\end{tabular}

Source: SAVezni Zavod Za Statistiku SFRJ: Census Results of Yugoslavia 1953, 1971, 1991; Popis stanovništva 2002 u Republici Makedoniji.

Figure 9: Albanians around 2000

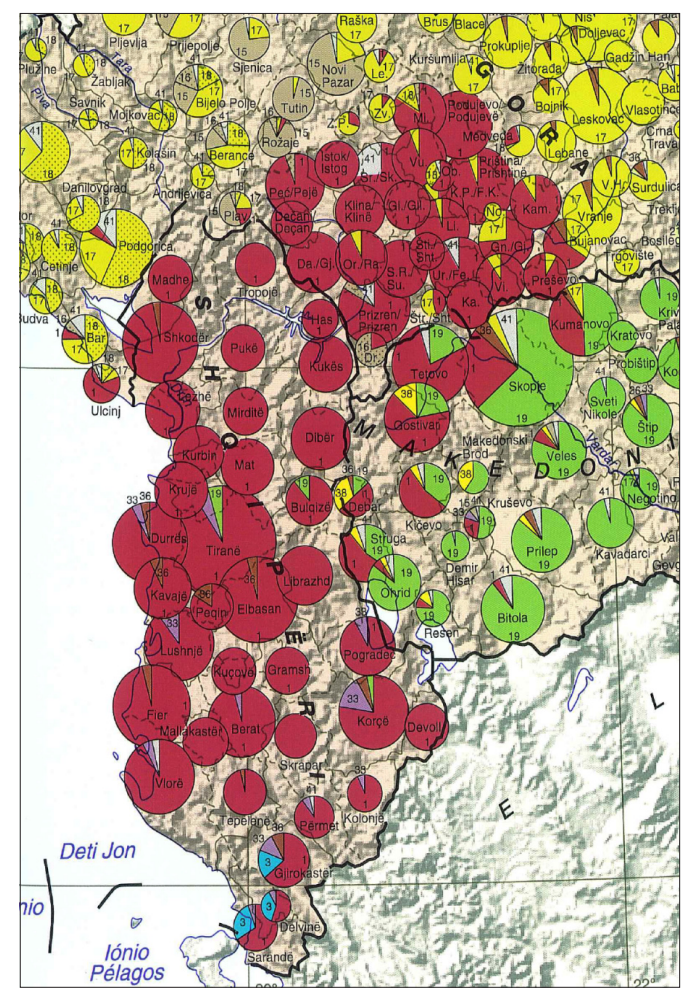

Source: JORDAN \& Kocsis et al. 2006 
As result of the sovereignty of states emerging on the territory of Ex-Yugoslavia, the ethnic consciousness changed dramatically not only towards strengthening the dominant ethnicity (which was a common reaction), but also towards questioning own roots. Montenegro could become a laboratory of a recent re-awakening of a dual nation. The dominant Montenegrin ethnic affiliation, which was the tradition since World War II, dramatically changed in 2006 as Montenegro succeeded from Yugoslavia. The independence referendum was with $55.5 \%$ on the margin to be successful and accepted by the EU. As result, the Montenegrin ethnic consciousness dropped from $62 \%$ in 1991 to $43 \%$ in 2011. At the same time Serb ethnic consciousness rose from 9 to $32 \%$ ! Regarding J. ZuPANČıč (2010) fieldwork results, dual identity, as an equally strong ethnic identity, is common among many Montenegrin citizens.

Figure 10: Montenegro: Ethnic structure according to census 2011

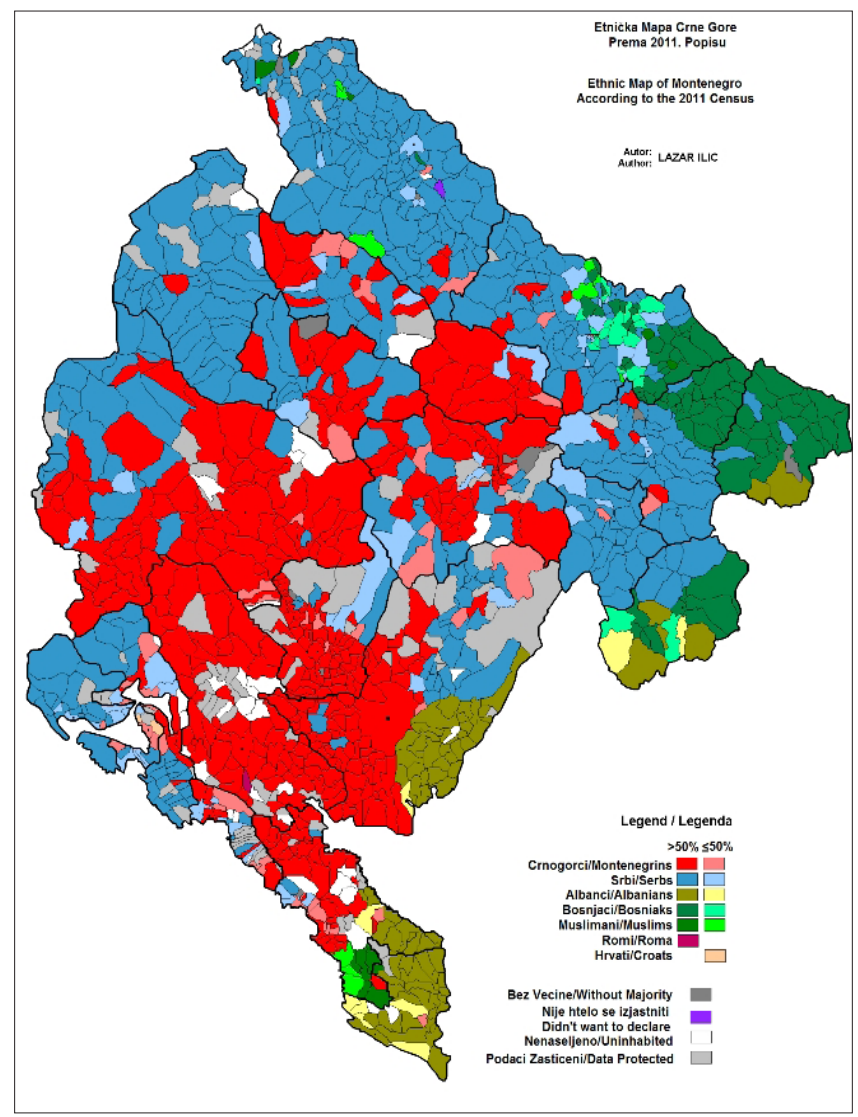

Source: Population census Montenegro 2011 
Table 3: Montenegro: Ethnic structure according to census 2011

\begin{tabular}{|l|r|r|r|r|}
\hline & $\mathbf{1 9 5 3}(\mathbf{\%})$ & $\mathbf{1 9 7 1}(\mathbf{\%})$ & $\mathbf{1 9 9 1}(\mathbf{\%})$ & $\mathbf{2 0 1 1}(\mathbf{\%})$ \\
\hline Montenegrin & 86,6 & 67,3 & 61,7 & 43,1 \\
\hline Serbian & $\mathbf{3 , 3}$ & $\mathbf{7 , 4}$ & $\mathbf{9 , 3}$ & $\mathbf{3 1 , 9}$ \\
\hline Albanian & 5,7 & 6,8 & 6,6 & 5,1 \\
\hline Muslim & 7,1 & 13,2 & 14,6 & 3.9 \\
\hline Bosniak & - & - & - & 7,8 \\
Croat & 2,3 & 1,7 & 1,0 & 1.0 \\
\hline Yugoslav & 1,5 & 2,1 & 4,2 & 0,3 \\
\hline other & 0,6 & 0,02 & 2,4 & 6,7 \\
\hline POPULATION & $\mathbf{4 1 9 . 9 0 0}$ & $\mathbf{5 2 9 . 6 0 0}$ & $\mathbf{6 1 5 . 0 0 0}$ & $\mathbf{6 2 0 . 0 0 0}$ \\
\hline
\end{tabular}

Source: SAvezni Zavod za Statistiku SFRJ: Census Results of Yugoslavia 1953, 1971, 1991; Population census Montenegro 2011

Individuals of former Yugoslavia change their ethnic cloth verbally according to their own interest, education and belief. Selectively they prioritise and re-rank their ethnic commitment by placing the ethnic identity, which they believe that suites their own beliefs, culture, economic status or other social strata better. Not necessarily to increase their individual comfort in the geo-political reality of the territory of living! I was drawn into the whirlwind of identities myself. In my Slovenian rural community of Logatec, the Simplon-Orient Express stopped for several years to switch the beautiful JDŽ 06 steam engine to the electric powered one - a heritage of the Italian rail in Western Yugoslavia. We, students migrating daily to the high school (Postojna), were

Figure 11: The Simplon-Orient Express changing to electric power in Logatec, Slovenia, 1960
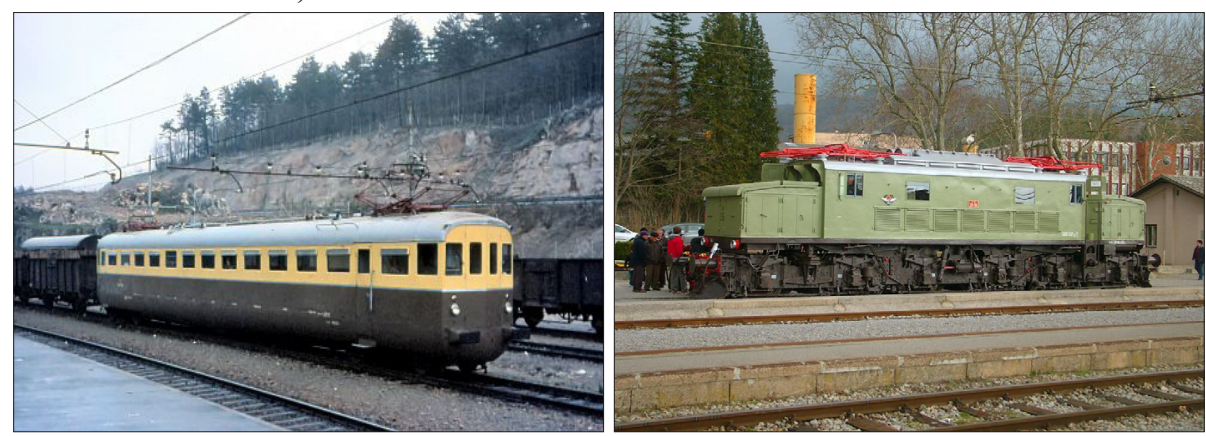
proud to have been able to use the ancient Italian Litorina to go and come back from the school.

I had no chance to survive with my Serbian in the Slovenian village where the cultural/economic impact of Italy was felt since World War I. I became excellent in Slovenian, moderated celebrations on Slovenian cultural heroes and became the spokesman for the Yugoslavian cause within the family. During my first two visits to my German relatives, who found their new home in the States (Minnesota), as a 12 and 16 year old kid, I have praised Tito and the Communist state and therewith shocked relatives, who lost all their Banat-Vojvodina property. As tour director for the travel agency Kompas, several years later, I became an expert for the "Classical Yugoslavian Tour" and was admired by British and American guests for my knowledge of the heritage on the Balkan soils. As the highlight of my Slovenian-Yugoslav identity I consider the fact that for several years (1977-1986) I was chosen to guide students of the High School for the Slovenian Minority in Carinthia, Austria, (Bundesgymnasium für Slowenen) on routes through Yugoslavia.

Figure 12: The author's German family re-union in St. Paul, Minnesota (left); author as the Yugoslavian guide to an American ethnic Slovenian tourist group
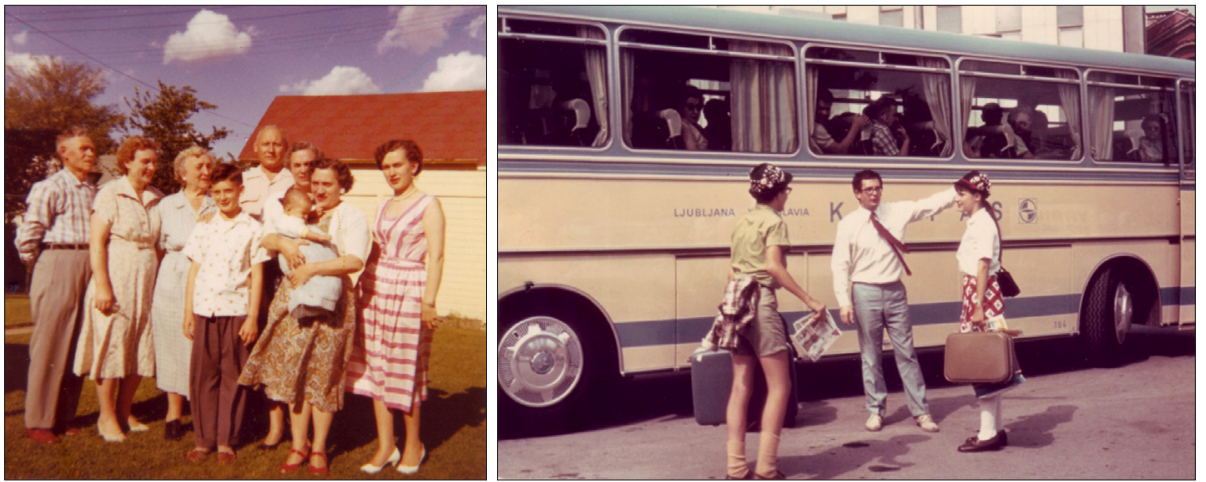

My Yugoslav identity overshadowed the possibility to remain in Munich [München], to where I was invited to contribute to the research on Yugoslav tourism. Instead, in the mid-1970s, I decided to join the Yugoslav People's Army! The questioning of the cultural/ethnic identity came alive much later, as I got in touch with several foreign schools of geography. The personal identity changed Yugoslavian to Slovenian by 1988 , as I joined the local "revolutionary" committee working towards democracy and secession from Yugoslavia and for Slovenia's sovereignty. The centralised state and Communism had to be eliminated!

This switch was finalised as I returned back home from several years of teaching at two American universities. Due to the ethnic wars in Croatia and Bosnia and 
Herzegovina it was senseless to stick to "Yugoslavism" there. After the visit of my Croatian friend Zlatko PEPEONIK and his talk to students and colleagues at my guestuniversity, I decided that I had to contribute to success of the new nation state of Slovenia as well. At the Washington IGU meeting, in 1992, I delivered an inspiring speech and soon returned back to Slovenia. It was a tough decision for me and my family because my hosting university, the University of Missouri, offered me "tenured track," which should have gone in effect immediately.

Figure 13: The author's ethnic consciousness under pressure: study and work environments leading to questioning own ethnic identity
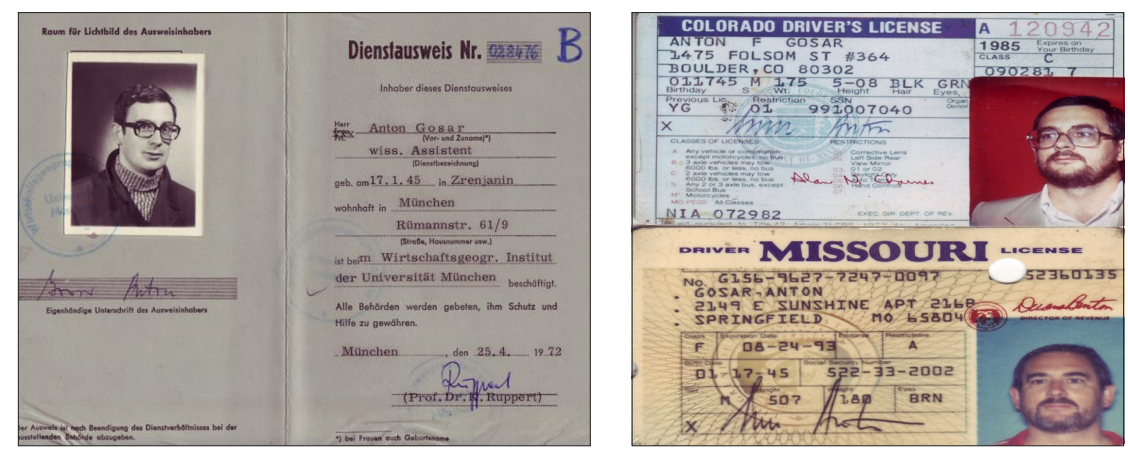

At the beginning, I liked the idea of the young and overwhelmingly patriotic/ nationalistic Slovenia. I joined the Slovenian foreign secretaries Lojze PETERLE and Dimitrij RUPEL on a couple of international trips (USA, Belgium). In particular I appreciated their vision of Slovenia as an equal member of nations of Europe. Diversity in Unity! The greatest achievement of the 1990s, as I saw it, was the final settlement of Yugoslavia's ethnic issues with western neighbours, in particular the issue of the Slovenian minority in Austria and Italy (in some geographic textbooks - Harm DE BLIJ - called "Yugoslavian irredentism"!), and the Italian and Austro-German property and heritage issue.

What I disliked about politics at that time was the hostile standpoint against former "brothers and sisters in arms". Disagreements regarding bank deposits, which left saving deposits at Slovenian banks in other new nation states in a long-term limbo (a decision made by the EU court changed this in 2014), the political wrestling about borders and other heritage issues questioned my identity again - in particular due to the fact that my own and Mladen KLEMENČIĆ's mapped solution of the border delimitation in the Adriatic Sea was put into drawers by politicians. 
Figure 14: Mladen KLemenčić (Croatia) and Anton Gosar (Slovenia): Proposal for the border delimitation in the Pirano Bay of the Adriatic Sea, 1999

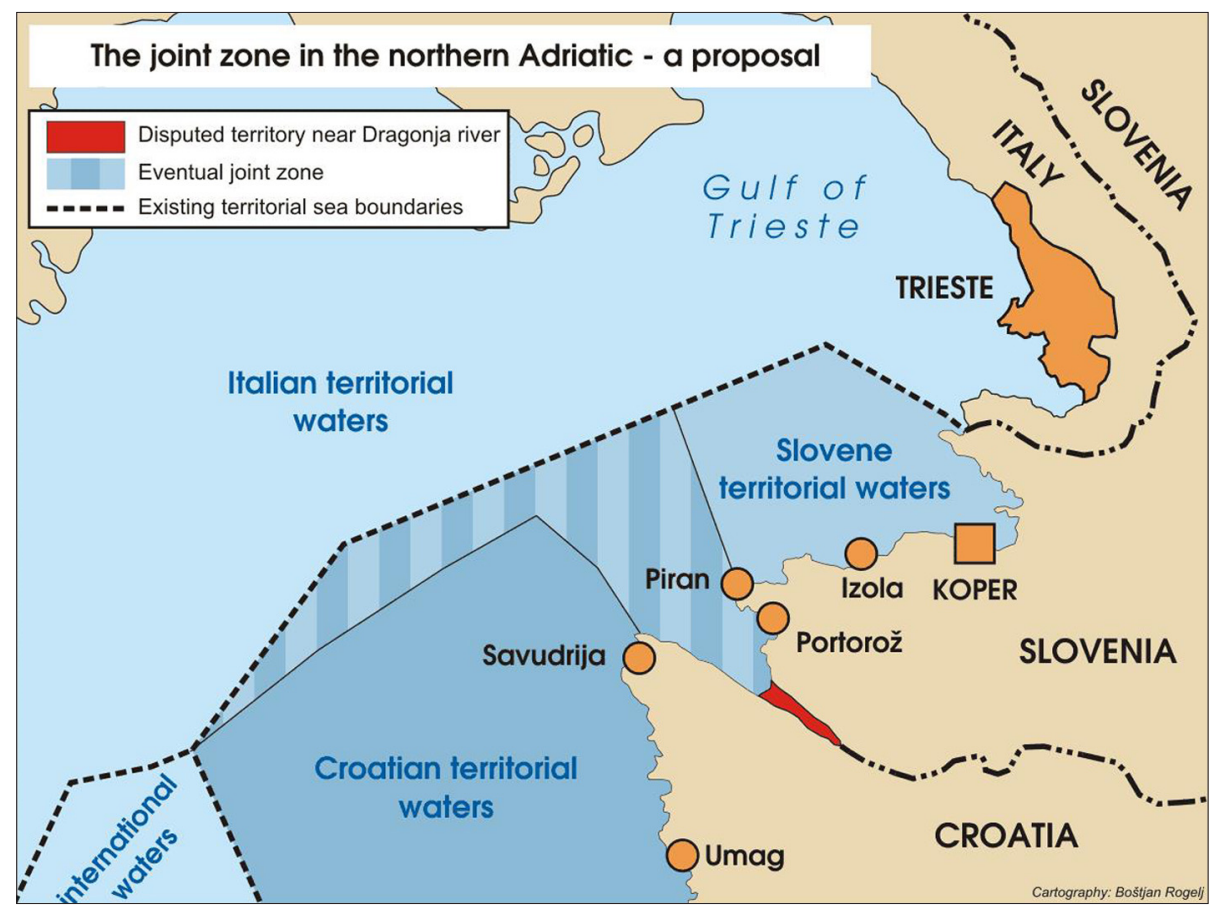

In 2004, Slovenia was considered to be the bright star of the EU accession countries. I was convinced that more European cooperation would lead to loss of national identity. But the idea that politics, education (exchange programs, European history lessons in schools) or social cohesion could make a contribution to a European identity has in fact been proven to be untrue. Several studies have shown that citizens associate themselves in the first instance with their own country and to a far lesser degree with Europe. In 2012, EuROSTAT concluded that "the determining factors for national identity seem to have changed, in particular since 2009. The emphasis on the most elusive, subjective concepts (feeling, sharing, believing) is diminishing, while there is a growing emphasis on the most objective, concrete concepts (places of birth of respondents and their parents, place of upbringing, language skills and civil rights)." The so called "hotchpotch identity" - a mixture composed of many unrelated parts has become European Union's reality in 2014. 
Table 4: Identification with EU citizenship ("European") in 2004 and 2012

\begin{tabular}{|l|r|r|r|r|}
\hline & $\begin{array}{c}\text { European } \\
\text { Only (\%) } \\
2004\end{array}$ & $\begin{array}{c}\text { European } \\
\text { First and } \\
\text { Only }(\%)\end{array}$ & $\begin{array}{c}\text { European } \\
\text { 2nd, 1st and } \\
\text { Only (\%) } \\
2004\end{array}$ & $\begin{array}{c}\text { European in } \\
\text { any of Identities } \\
(\%) \text { 2004/2012 }\end{array}$ \\
\hline Luxembourg & 7 & 10 & 40 & $57 / 85$ \\
\hline Malta & 0 & 2 & 54 & $56 / 72$ \\
\hline Cyprus & 2 & 6 & 45 & $53 / 62$ \\
\hline Belgium & 4 & 8 & 40 & $52 / 69$ \\
\hline France & 4 & 6 & 42 & $52 / 65$ \\
\hline Slovenia & 1 & 4 & 46 & $51 / 66$ \\
\hline Germany & 3 & 8 & 38 & $49 / 74$ \\
\hline Italy & 2 & 5 & 42 & $49 / 45$ \\
\hline Czech Republic & 2 & 7 & 36 & $47 / 52$ \\
\hline Denmark & 2 & 8 & 37 & $47 / 75$ \\
\hline Slovakia & 2 & 5 & 40 & $47 / 70$ \\
\hline EU - 25 & 2 & 6 & 37 & $45 / 61$ \\
\hline Austria & 2 & 5 & 35 & $42 / 60$ \\
\hline Croatia & 1 & 4 & 47 & $52 / 48$ \\
\hline Turkey & 2 & 1 & 15 & $18 / 20$ \\
\hline
\end{tabular}

Source: EuROSTAT 2012

In conclusion: political and economic policies, cultural and religious beliefs and subjective decisions have since 2004 (as Peter JORDAN in the Atlas of Eastern and Southeastern Europe published his map on ethnic consciousness in East-Central Europe) produced six general types of identities:

Strengthened ethnic identity, which extended into increased patriotism and nationalism, but also into chauvinism and irredentism;

A limbo identity, resulting out of the disintegration of Yugoslavia as about four million refugees and displaced people, residing in foreign lands, live either in their "dream world" (of Yugoslavia) and/or are shunning the identity of the new nation state;

Dual-ethnic identity being a phenomenon in particular of Montenegro where the division between Montenegro's culture and the one of the Serbs is not set (yet); 
Hotchpotch identity is marketed by EU member states (of the region as well) where the mixture of many unrelated ethnic components is positively promoted in slogans like "diversity in unity";

Fluid identity relates to the process of a continuous switch of identities on the ethnic or citizenship platform - like changing national ethnic identity to European citizenship;

Pan-European identity is to be perceived as the envisioned political process of the 2004 enlargement of the EU, which has proven to be an illusion if related only to European identity, but has many followers if combined with ethnic/national identity.

Some rare co-passengers on the Simplon Orient Express have converted from their (questionable) genetic, ethno-cultural and geographic places of origin to become European. My own identity search, from Serb to European, has been a process, which ended at this stage. Despite my New and Old World experience, I cannot consider myself "cosmopolitan", since I have no clue of the politically, economically and culturally emerging Far-East identities ...

\section{References}

Bоттцік Z. (2008), Zu den ethnischen Disparitäten in Makedonien während der Transformation. In: Europa Regional, 16, 2, pp. 54-63.

Bulard M. et al. (2012), Europas Balkan. Atlas der Globalisierung: Die Welt von morgen. Le Monde Diplomatique, Paris, pp. 114-115.

Cattaruzza A. (2004), Les Representations de L'espace Politique et Culturel chez les Jeunes de Bosnie-Herzegovine. In: Richard Y., SAnguin A.-L. (eds.), L'Europe de L'Est Quinze Ans Apres La Chute du Mur, pp. 309-330. Paris, Harmattan.

Gosar A. (2010), Kako sam postao Europljanin. In: Hrvatska revija, 10, 3, pp. 53-57.

Hasic T. (2004), Ethnic Conflict and the Right to Return of Limbo Diasporas: Multifaceted Reflections on the Case of $\mathrm{BiH}$. In: Migracijske i etničke teme, 20, 1, pp. 7-29.

Hupchick P.D., Cox E.C. (2001), The Palgrave Concise Historical Atlas of The Balkans. New York, Palgrave.

Jordan P., Kocsis K. et al. (2006), Ethnisches Bewusstsein in Mittel- und Südosteuropa um 2000/Ethnic consciousness in Central and Southeast Europe around 2000. In: JORDAN P. (ed.), Atlas Ost- und Südosteuropa/Atlas of Eastern and Southeastern Europe, 2.9-G9. Stuttgart, Borntraeger.

KLEMENČIČ V. (1991), Spreminjanje nacionalne strukture prebivalstva Jugoslaije v novejšem obdobju. In: Geografija v šoli. Zbornik referatov seminarja permanentnega izobraževanja: 5. Ilešičevi dnevi, pp. 7- 23. Ljubljana, Oddelek za geografijo Filozofske fakultete Univerze v Ljubljani, Zveza geografskih društev Slovenije.

KLEMENČIČ V. (1991), Spreminjanje nacionalne strukture prebivalstva Jugoslavije v novejšem obdobju. In: Geografija v šoli, 1, pp. 7-23. 
KLEMENČí M. (2006), Ethnic Maps: Between Reality and Propaganda. In: Migracijske i etničke teme, 22, 4, pp. 363-378.

Lange Y., Bijman R. (2012), Euromyths (9/10): national identity just hasn't been eroded. In: De groene Amsterdammer, 2 August 2012.

PaK M., Slavec A. (1992), Rast števila in narodnostnega sestava prebivalstva Hrvaške, Bosne in Hercegovine ter Vojvodine med letoma 1981 in 1991. In: Geografski obzornik, 20, 3, pp. 26-32.

Rowan R., BiRns J. (1950), LIFE rides the Simplon-Orient Express. Europe's most famous train has lost its luxury but kept its air of intrigue. In: LIFE, September 11, 1950, pp. 137-145. On LIFE photo archive hosted by Google <https://www.google.com/search?q=SimplonO rient+Express\&q=source\%3Alife\&gws_rd=ssl\&tbm=isch $>$

SAVEZni Zavod Za StatistikU SFRJ (1991), Nacionalni sastav stanovništva po opštinama. Prvi rezultati Popisa stanovništva, domaćinstava, stanova i poljoprivrednih gazdinstva 1991. godine. Beograd.

SöLCH W. (1974), Orient Express. Glanzzeit und Niedergang eines Luxuszuges. Düsseldorf, Alba-Buchverlag.

TeCCO S. (2014), Trk dveh vlakov. Samoodločba po katalonsko ali po jugoslovansko. In: Objektiv, 30. October, Ljubljana, pp. 12-13.

ZUPANČIČ J. (2010), Geopolitične razsežnosti črnogorskega narodnega vprašanja. In: Treaties and Documents, Journal of Ethnic Studies, 61, pp. 8-42.

ŽulJÍ́ S. (1989), Narodnostna struktura Jugosavije i tokovi promjena. Zagreb, Ekonomski institut. 